\title{
THE CALCULATION OF THE CONTACT FORCE AND THE CONTACT WIDTH OF SHAFT SEALS
}

\author{
$\breve{S ̆ L E S A R ~ P e t e r ~}^{1}$, JANČO Roland ${ }^{2}$

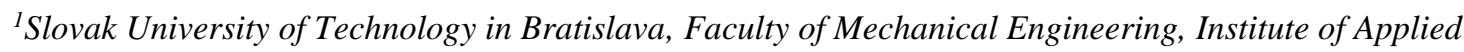 \\ Mechanics and Mechatronics, Nám. Slobody 17,812 31 Bratislava, Slovakia,e - mail: peter.slesar@stuba.sk \\ ${ }^{2}$ Slovak University of Technology in Bratislava, Faculty of Mechanical Engineering, Institute of Applied \\ Mechanics and Mechatronics, Nám. Slobody 17,812 31 Bratislava, Slovakia, e - mail: roland.janco@stuba.sk
}

\begin{abstract}
The aim of the article is to point out the sealing efficiency of the two-language seal of the water pump bearing when radially deflecting the shaft within radial clearance. In order to obtain a radial displacement of the shaft at a location under a two-language seal, dynamic bearing simulation was performed using the MSC Adams program. The largest radial deviation of the shaft was applied in final seal analysis where the contact pressure changes on the individual tongues of the seal were recorded.
\end{abstract}

KEYWORDS: water pump, MSC Adams, radial clearance, seal, contact status

\section{Introduction}

The first record of the patent on the ball of the bearing originates from the end of the 18th century. The use of rolling bearings has taken place a guiding role against the developing one to the Industrial revolution, what efficient operation new industrial machinery [1].

A pump is a device that moves fluids (liquids or gases), or sometimes slurries, by mechanical action. Pumps can be classified into two major groups according to the method they use to move the fluid: direct lift, displacement, and gravity pumps [2, 7]. Pumps operate by some mechanism (typically reciprocating or rotary), and consume energy to perform mechanical work moving the fluid. Pumps operate via many energy sources, including manual operation, electricity, engines, or wind power, come in many sizes, from microscopic for use in medical applications to large industrial pumps [2, 3, 8].

Mechanical pumps serve in a wide range of application s such as pumping water from wells, aquarium filtering, pond filtering and aeration, in the car industry for water-cooling and fuel injection, in the energy industry for pumping oil and natural gas or for operating cooling towers. In the medical industry, pumps are used for biochemical processes in developing and manufacturing medicine, and as artificial replacements for body parts, in particular the artificial heart and penile prosthesis. When a casing contains two or more revolving impellers, it is called a double- or multi-stage pump [1].

\section{Dynamic simulation}

The two-language seal located in the bearing serves to prevent the ingress of impurities and water into the bearing at given shaft revolutions. The task of dynamic analysis was to determine the magnitude of the deflection of the shaft at given shaft revolutions. The detected deviations from the dynamic analysis were further applied in the seal contact analysis. 


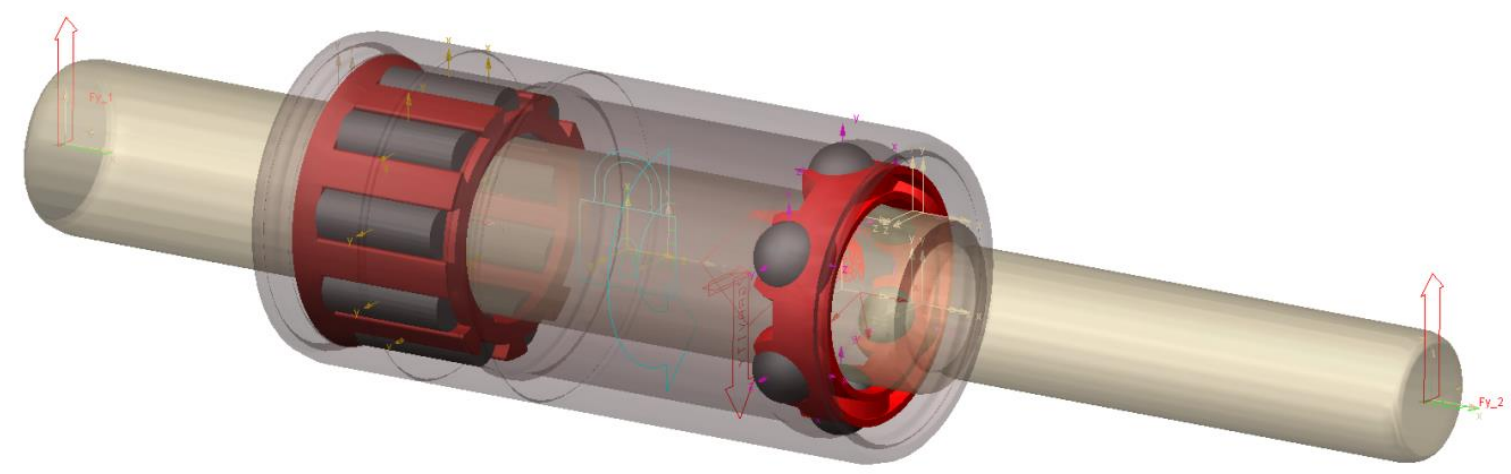

Fig. 1 Model for dynamic simulation

During the dynamic bearings simulation, all degrees of clearance are removed. Bindings of other components are defined by contacts. Critical contact pair for achieving the right results is the contact of rolling bodies with orbits. For this contact, parameters were selected as follows: Stiffness $=1 \mathrm{E}+7$, Force Exponent $=1.2$, Damping $=10$, Penetration Depth $=0.001$.

The load on the shaft is chosen to define the radial clearance of the bearing. For this purpose, two forces were applied at the ends of the $10 \mathrm{~N}$ shaft, which in the first half of the simulation have the same orientation and in the other half opposite to simulate the tilting. One load step lasted $1 \mathrm{~s}$. The total analysis simulation lasted $4 \mathrm{~s}$. Figure 2 shows the bearing load. The shaft speed $(\mathrm{n}=7 \mathrm{rpm})$ for simulation was selected to capture the entire cage speed

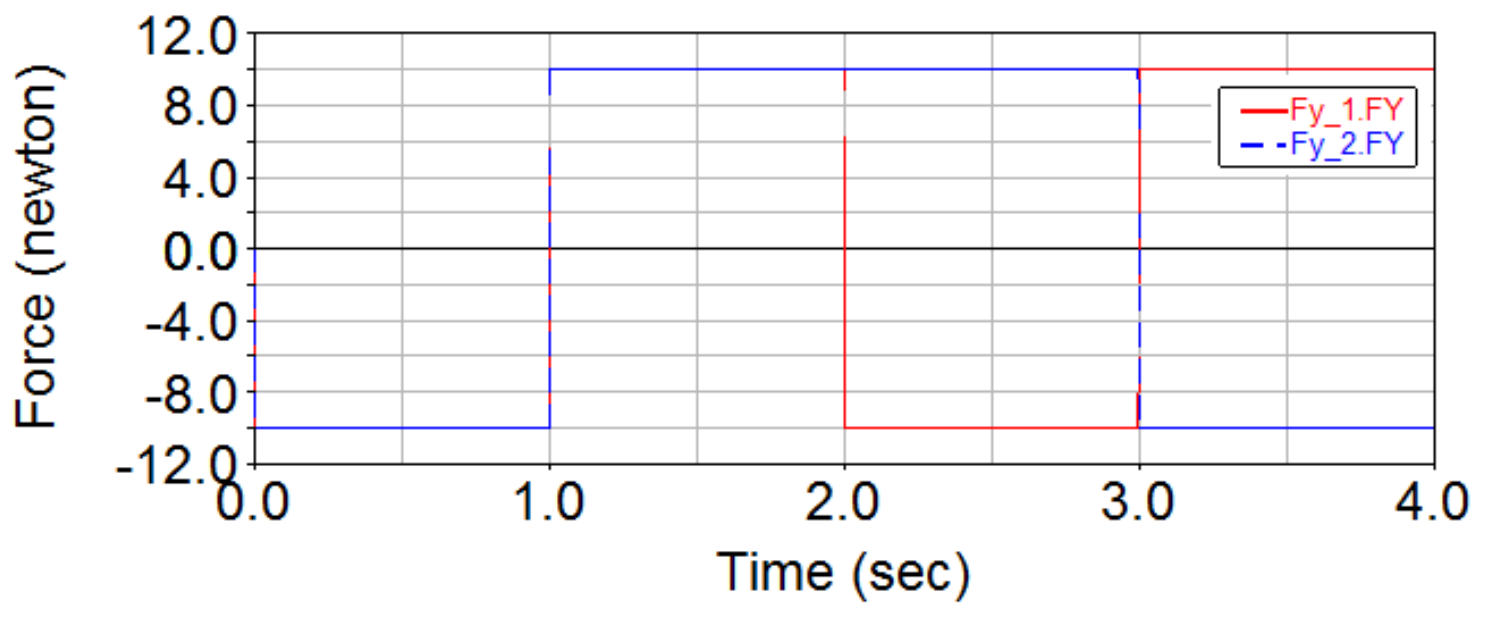

Fig. 2 Bearing load

Fig. 3 shows the course of the shaft deflection under the two-language seal on the side of the ball track - under the two-language seal. The curve swinging is caused by the contact body rotation and the gap in the contact area. Maximum subtraction of the shaft under the two-lane seal: i.e. on the side of the sphere is $0.030 \mathrm{~mm}$. 


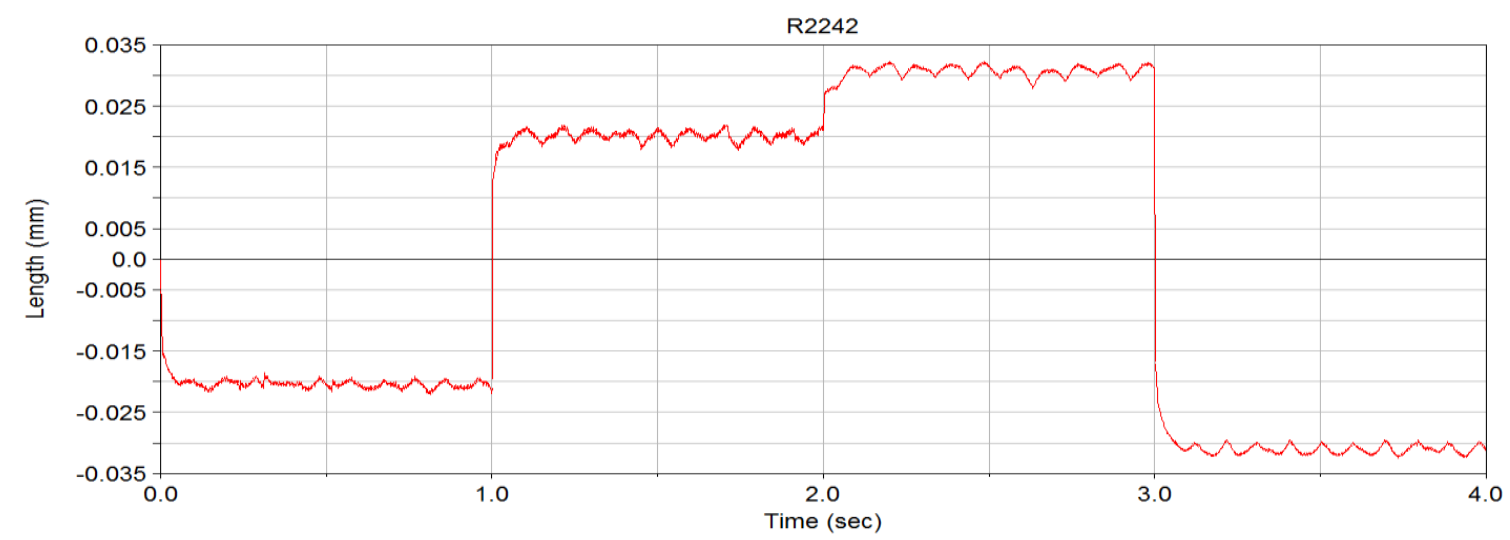

Fig. 3 Shaft deflection

\section{Analysis of the bearing of the bearing in the body}

The deformation of the case is $0.030 \mathrm{~mm}$. This value was determined based on press-fit analysis. In this analysis, the housing sleeve is pressed into the body at a temperature of $20^{\circ}$ $\mathrm{C}$ and then cooled to the starting temperature of the bearing.

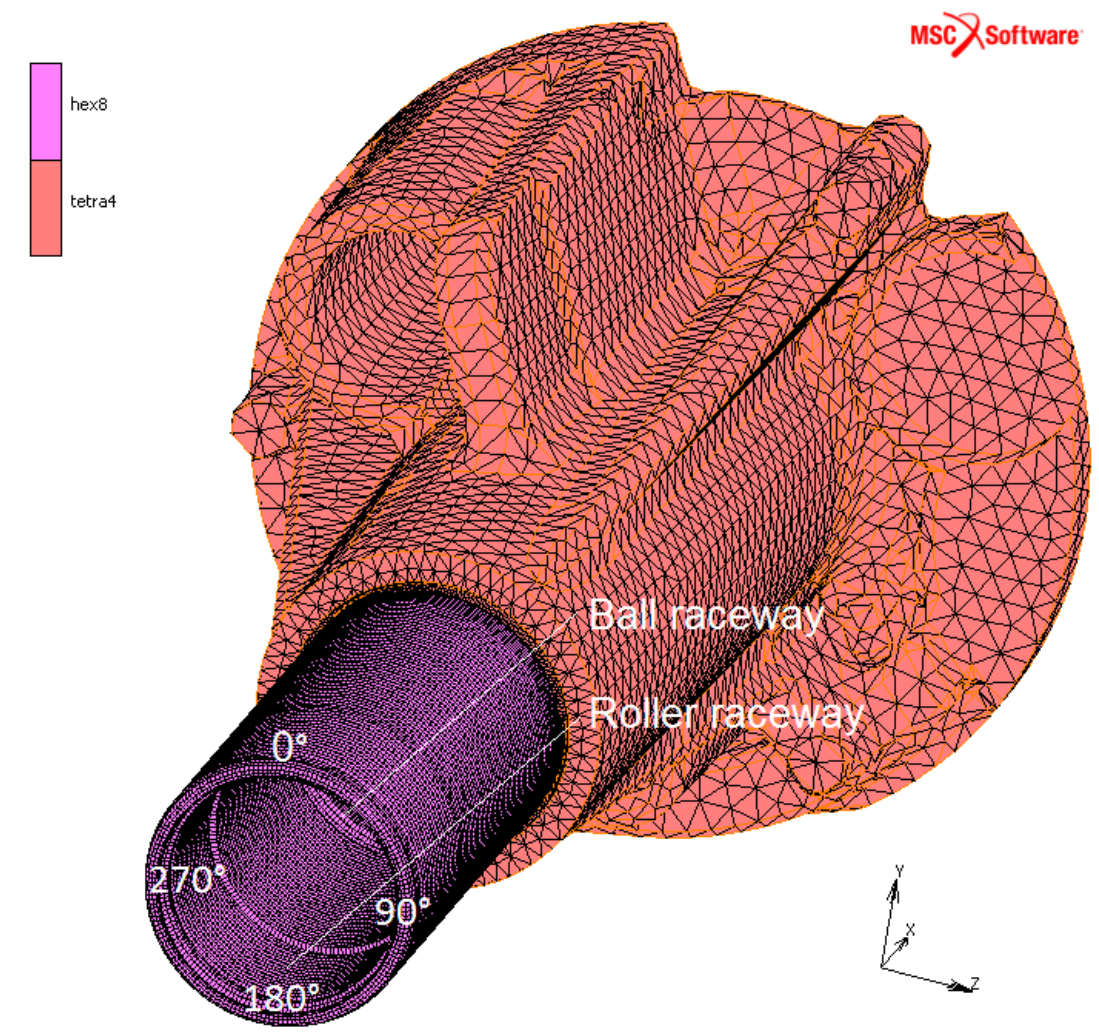

Fig. 4 Model for thermal / structural analysis

For the calculation of aluminium part is used bilinear material model of AlSi9Cu with the Young's modulus $E=69.000 \mathrm{~N} / \mathrm{mm}^{2}$, Yield strength $R_{\mathrm{e}}=140 \mathrm{MPa}$, Ultimate strength $\mathrm{R}_{\mathrm{m}}=240$ $\mathrm{MPa}$, Elongation $\mathrm{A}_{50 \mathrm{~mm}}=1 \%$, Poisson's ratio $\mu=0.3$ and linear thermal expansion coefficient $\alpha=21 \times 10^{-6}{ }^{\circ} \mathrm{K}$. For the calculation of steel parts was used elastic material model of $100 \mathrm{Cr} 6$ with the Young's modulus $\mathrm{E}=210.000 \mathrm{~N} / \mathrm{mm}^{2}$, Poisson's ratio $\mu=0.3$ and linear thermal expansion coefficient $\alpha=11.7 \times 10-6^{\circ} \mathrm{K}[6]$. 
Analysis model is modified due to eliminate unnecessary details and is set up in FEA environment. Housing is meshed by using aprox. 110.000 of 3D elements type: TETRA 4 (4 nodes tetrahedron). Outer ring of bearing is meshed by using aprox. 42.000 of $3 \mathrm{D}$ elements type: HEX 8 ( 8 nodes hexahedron).

Boundary conditions: Housing is fixed and outer ring of bearing has defined displacement to press-fit outer ring into final position. Analysis is carried out by using implicit solver.

The bearing is then heated to operating temperature and deformation of the orbital paths in the bearing is observed. Fig. 4 shows the deformation of the ball orbit at the initial temperature. In this mode, the case is critically depressed.

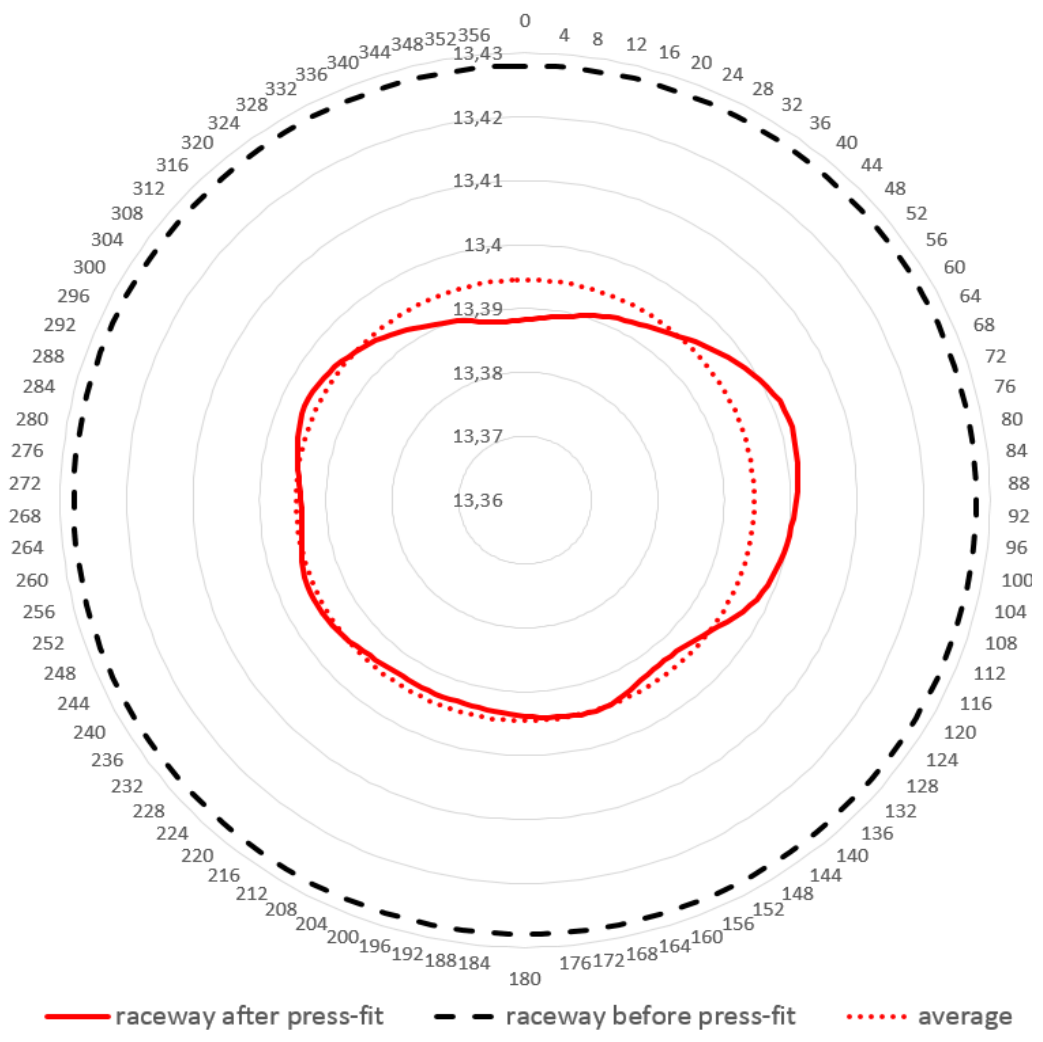

Fig. 5 Ball raceway deformation at starting temperature

\section{Seal efficiency analysis for radial shaft deflection}

The purpose of the analysis is to find out whether the seal after the bearing operation and the radial shaft swing application meet the tightness requirements. This means that the seals are completely adhered to the surface and how the contact pressure varies with the surface.

The axisymmetric calculation model (Fig. 5) consists of the components of the housing, shaft, sealing dish, sealing, and pusher. In the first step of the simulation, the seal is pressed into the recess of the housing, then a radial displacement of $0.030 \mathrm{~mm}$ is applied to the housing, simulating the pressing of the bearing into the body. In the last step, the shaft is radially deflected to the extreme positions +0.030 and -0.030 compared to its nominal position.

When creating a finite-element network, quad4 was used:

For Steel Type: Full Integration 10 
For rubber type: Full and Herman formulation 82

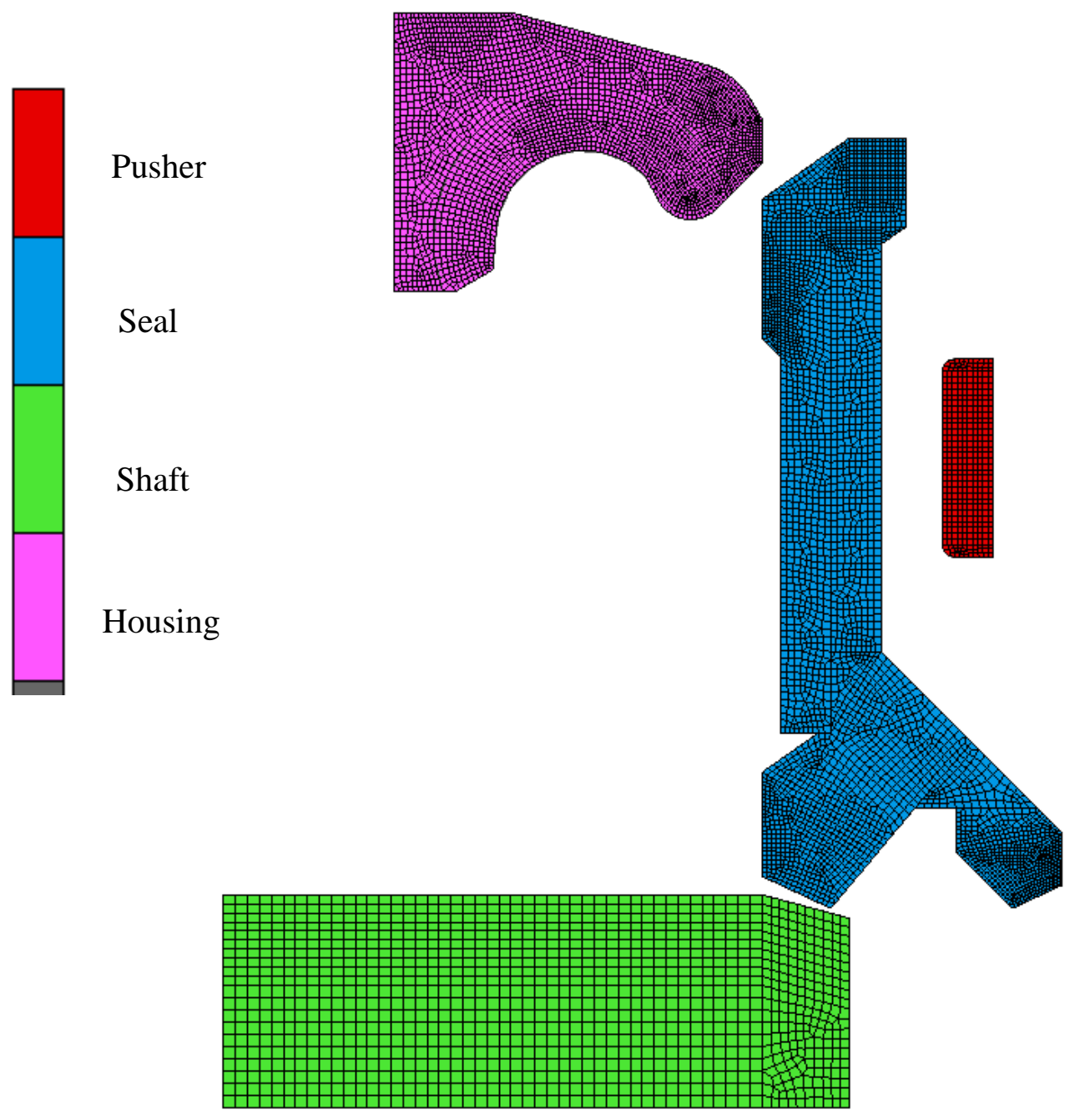

Fig. 6 The Axisymmetric calculation model

The casing and shaft material is made of steel, which is directly defined in the MSC Marc database. Young Elastic Module E $=210000 \mathrm{MPa}$. Sealing rubber material is specified by two Mooney-Rivlin parameters for hyperelastic materials. The value of constants $\mathrm{C} 10=0.789808$ $\mathrm{MPa}$ and $\mathrm{C} 01=0.284992 \mathrm{MPa}[4,5]$.

\section{$5 \quad$ Results}

Change of pressure from individual language is shown in Table 1. Fig. 7 shows the designation of the individual languages. Contact force are depicted in Fig. 8.

Table 1 shows the value of the contact normal forces at the front and back of the lip and the seal width of the contact area under the two lips.

Table 2 shows the contact force and width of contact area of shaft on the front lip for various radial clearance. 


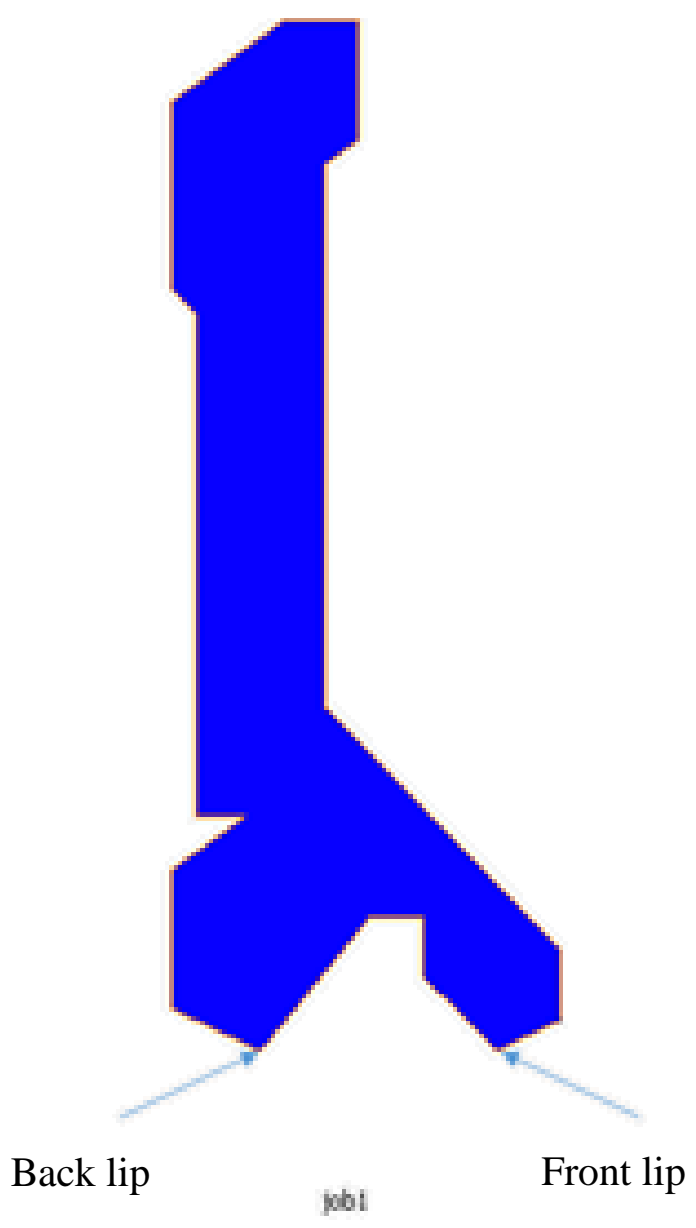

Fig. 7 Designation lip seal

Table 1 The contact normal forces and the seal width of the contact area

\begin{tabular}{|l|c|c|c|}
\hline Seal & $\begin{array}{c}\text { Force } \\
(\mathbf{N})\end{array}$ & $\begin{array}{c}\text { Width of the contact } \\
\text { area (mm) }\end{array}$ & $\begin{array}{c}\text { Maximum contact normal } \\
\text { stress } \\
\text { (MPa) }\end{array}$ \\
\hline & & & 1,45 \\
\hline Front lip & 1,45 & 0,03 & 1,02 \\
\hline Back lip & 11,25 & 0,106 & \\
\hline
\end{tabular}

Table 2: The contact force and width of contact area for various radial clearance.

\begin{tabular}{|c|c|c|c|}
$\begin{array}{c}\text { Clearance } \\
(\mathbf{m m})\end{array}$ & $\begin{array}{c}\text { Width of the contact area } \\
(\mathbf{m m})\end{array}$ & $\begin{array}{c}\text { Contact force } \\
(\mathbf{N})\end{array}$ & $\begin{array}{c}\text { Maximum contact normal } \\
\text { stress } \\
(\mathbf{M P a})\end{array}$ \\
\hline 0 & 0,0236 & 0,953 & 0,96 \\
\hline 0,025 & 0,0236 & 0,848 & 0,89 \\
\hline 0,040 & 0,0209 & 0,770 & 0,85 \\
\hline
\end{tabular}




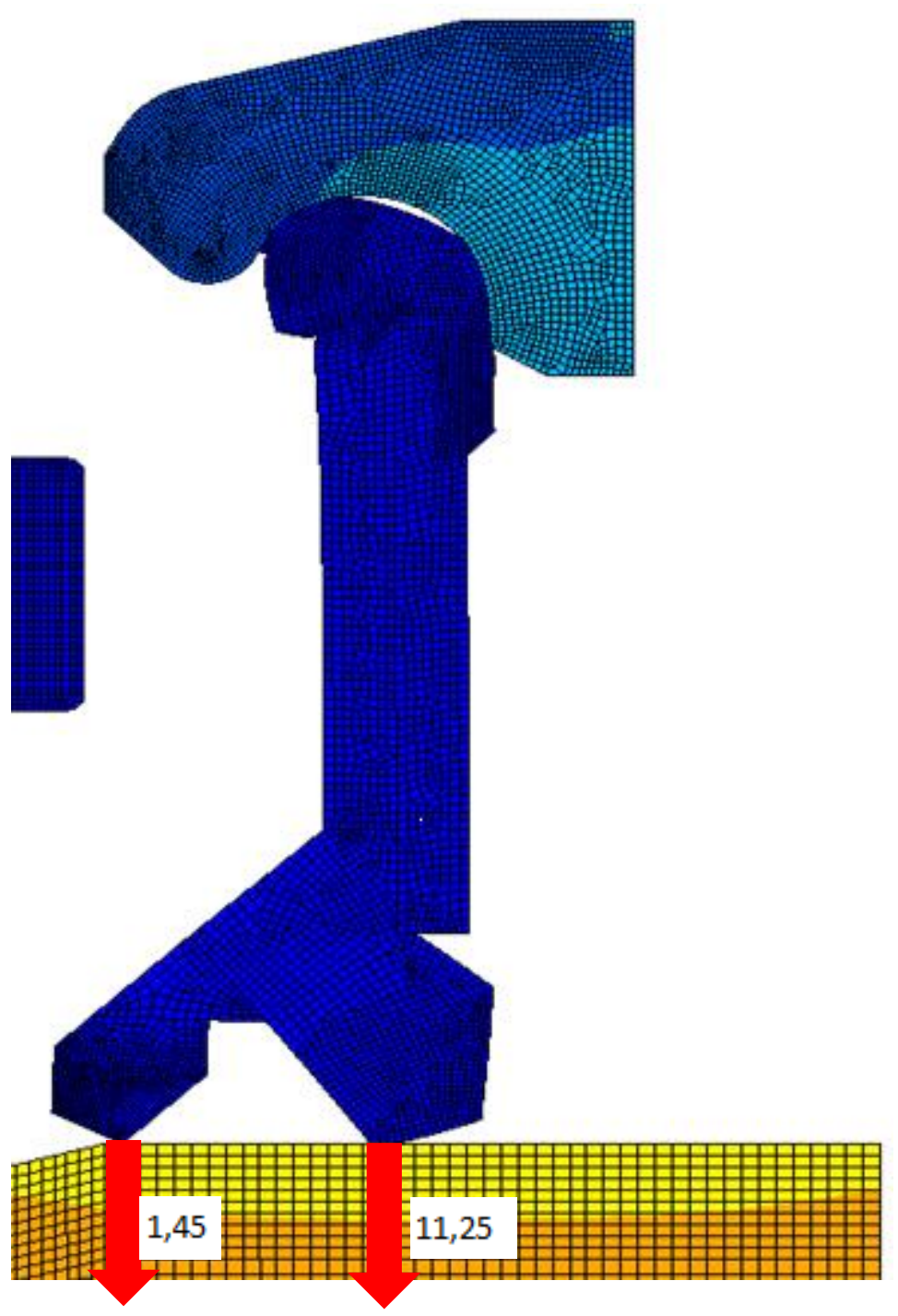

Fig. 8 Contact force for the back and front lip

\section{CONCLUSION}

By dynamically simulating, the maximal shaft output under the two-language seal could be identified for the selected load, when determining the radial clearance. The largest deflection occurred when tilting the shaft t.j. $0.033 \mathrm{~mm}$. This value was then used in the final analysis of the seal inspection. After applying the displacement from the casing to the body and the limit shaft extensions, neither one of the language is completely deviated. Table 1 shows the change in pressure from individual languages. In terms of size and change in contact pressure, the most critical front lip.

\section{ACKNOWLEDGEMENTS}

The paper was supported by the grant from KEGA no. 017STU-4/2018 entitled "Theoretical and Practical Solution of Structures on Elastic Linear and Nonlinear Foundation". 


\section{REFERENCES}

[1] Smrček O. "Stručné dějiny oborů -Strojírenství", Praha, Scientia, 2006. ISBN: 80$7183-247-2$

[2] Pump classifications. Fao.org. Retrieved on 2011-05-25.

[3] Improving Pumping System Performance: A Sourcebook for Industry, Second Edition, May 2006. Accessed 2015-05-22.

[4] Billings, L. J., Shepherd, R. "The Modeling of Layered Steel/Elastomer Seismic Base Isolation Bearings," Proc. 1992 MARC Users Conference, Monterey, California, September 3-4, 1992.

[5] Bretl, J. L. "Implementation of the Elastomer Tearing Energy Approach in Finite Element Analysis," Proc. 1988 MARC Users Conference, Monterey, California, pp. 17 - 34, April 7-8, 1988.

[6] MSC-MENTAL, Advanced Nonlinear Simulation Solution, MSC Software Corporation, 2015.

[7] Owsinski, R., Nieslony, A. "Identification of Fatigue Cracks on the Basis of Measurable Changes in System Dynamics", Journal of Mechanical Engineering - Strojnícky časopis 67 (2), pp. 77 - 84, 2017. DOI: 10.1515/scjme-2017-0020

[8] Trebuňa, F., Šimčák, F. "Elasticity, strength and plasticity in mechanical engineering", Edition of scientific and special publications - Faculty of Mech. Eng. TU in Kosice, Emilena, Košice 2005. ISBN 80-8073-276-0.

[9] Šlesar, P., Jančo, R. "Press-Fit Evaluation and Study of displacement in Temperature Changes", Journal of Mechanical Engineering - Strojnícky časopis 68 (1), pp. 103 108, 2018. DOI: $10.2478 /$ scjme-2018-0011

[10] Pástor, M., Frankovský, P., Hagara, M., Lengvarský, P. "The Use of Optical Methods in the Analysis of the Areas with Stress Concentration", Journal of Mechanical Engineering - Strojnícky časopis 68 (2), pp. 61 - 76, 2018. DOI: 10.2478/scjme-20180018 